\title{
Detection of infectious Brome mosaic virus in irrigation ditches and draining strands in Poland
}

\author{
Małgorzata Jeżewska • Katarzyna Trzmiel • Aleksandra Zarzyńska-Nowak
}

Accepted: 29 June 2018 / Published online: 5 July 2018

(C) The Author(s) 2018

\begin{abstract}
Environmental waters, e.g. rivers, lakes and irrigation water, are a good source of many plant viruses. The pathogens can infect plants getting through damaged root hairs or small wounds that appear during plant growth. First results demonstrated common incidence of Tobacco mosaic virus (TMV) and Tomato mosaic virus (ToMV) in water samples collected from irrigation ditches and drainage canals surrounding fields in Southern Greater Poland. Principal objective of this work was to examine if environmental water might be the source of viruses infective to cereals. The investigation was focused on mechanically transmitted pathogens. Virus identification was performed by biological, electron microscopic, serological and molecular methods. Preliminary assays demonstrated Brome mosaic virus (BMV) infections in symptomatic plants inoculated with 9 out of the 17 tested concentrated water samples. The final identification was confirmed by molecular methods for selected isolates named: BMV-Ch1, -DBS, -N, -R and -S. Partial coding sequences of polymerase 1a (RNA1) and 2a (RNA2) and complete nucleotide sequence of coat protein (CP) gene (RNA3) of each BMV isolate were determined and compared with corresponding sequences of other known BMV isolates.
\end{abstract}

M. Jeżewska $\cdot$ K. Trzmiel $(\bowtie) \cdot$ A. Zarzyńska-Nowak Institute of Plant Protection-National Research Institute, Władysława Węgorka 20, 60-318 Poznań, Poland e-mail: k.trzmiel@iorpib.poznan.pl
Results confirmed the highest amino acid sequence homology in the fragment of polymerase $2 \mathrm{a}(99.2 \%$ - $100 \%)$ and the most divergence in CP (96.2\% $100 \%)$. This is the first report on the detection of an infective cereal virus in aqueous environment.

Keywords BMV . Water-borne virus · Cereals · RT-PCR

The occurrence of plant viruses in aqueous environment was studied less intensively than other water-borne viruses having impact on human health. Mehle and Ravnikar (2012) thoroughly reviewed the reports and listed 16 plant virus species isolated from different water sources, mainly from Europe, but not from Poland.

The main objective of our work was to fulfil this gap with special attention focused on infective cereal viruses. According to data of the Central Statistical Office cereals are the most important crops in Poland with the total acreage in 2016 amounted to $71 \%$ of the whole sown area (https://stat.gov.pl/obszary-tematyczne/rocznikistatystyczne/roczniki-statystyczne/maly-rocznikstatystyczny-polski-2017,1,18.html). Furthermore, there is only poor knowledge on this problem, perhaps because infective water-borne plant viruses are generally transmitted mechanically and cereal viruses are mostly vectortransmitted (aphids, leafhoppers, mites, soil-inhabiting organisms and other organisms).

First investigation provided evidence for the tobamoviruses incidence in water samples collected in irrigation ditches and draining strands surrounding fields in Greater Poland, an agriculture region of Poland 
(Jeżewska et al. 2018). Subsequently the attention was focused on the identification of a spherical virus causing disease symptoms in mechanically inoculated barley (Hordeum vulgare) and wheat (Triticum aestivum) as well as in pigweed (Chenopodium quinoa) plants.

The sampling was performed in spring 2017 in southern part of Greater Poland. New plastic bottles 0.51 were used for collecting water from irrigation ditches and draining canals surrounding cereal fields. The material was collected from 17 locations. Two portions of water from each site were considered as one sample for further analyses. Each sample, 11 of water, was submitted to low-speed centrifugation $(10,000 \mathrm{rpm}$ for $10 \mathrm{~min}$ in a Beckman Coulter Avanti J-26 XPI centrifuge). The pellet was re-suspended in $2 \mathrm{ml}$ of $0.05 \mathrm{M}$ potassium phosphate buffer $\mathrm{pH} 7.0$ containing carborundum and used for mechanical inoculation of test plants while the supernatant was taken for ultracentrifugation in a Beckman Coulter Optima L-90 K ultracentrifuge (30,000 rpm, $2 \mathrm{~h})$. The sediment was re-suspended in inoculation buffer to be used as inoculum as described above. The second supernatant was discarded.

Both sediments used for inoculation contained infectious viruses as it was demonstrated by biological assays and confirmed by electron microscopy observations. The sets of test plants, including: three tobacco (Nicotiana tabacum cv. Xanthi), seven pigweed (C. quinoa), four wheat (T. aestivum cv. Muszelka) and four barley (H. vulgare $\mathrm{cv}$. Conchita), were mechanically inoculated with water samples. The plants were maintained in insect proof, closed, monitored compartments, in standard glasshouse conditions ( $16 \mathrm{~h}$ of light and $8 \mathrm{~h}$ of darkness at $23^{\circ} \mathrm{C}$ ). The systemic infection was observed in each inoculated cereal plants, however with different intensity. The cereal plants reacted on the inoculation with nine out of 17 investigated concentrated water samples. Barley plants reacted vigorously, displaying strong mosaic with necrotic stripes 10 days postinoculation (Fig. 1a) while wheat plants developed only mild leaf mosaic. All tested tobacco plants reacted with local symptoms typical for tobamoviruses and all C. quinoa plants developed local lesions about $3 \mathrm{~mm}$ in diameter appearing on leaves after 3-5 dpi (Fig. 1b). The sap of cereal symptomatic plants was used to inoculate other test species including 4 sweet maize (Zea mays ssp. saccharata cv. Waza) and 4 oat (Avena sativa cv. Arden) plants. All maize plants reacted with leaf streaks and stunting followed by systemic necrosis or even death, about 28 dpi (Fig. 1c), as is typical symptoms on this species for Brome mosaic virus (BMV) infection. No clear disease symptoms were seen in inoculated oat plants.

Samples for the electron microscopy were prepared directly from symptomatic leaves. Carbon coated grids were incubated for 1-2 min at room temperature. The grids were then rinsed with a flow of drops of water. After rinsing the grids were stained with 6-7 drops of $2 \%$ aqueous phosphotungstic acid. Preparations were examined in a Hitachi HT7700 transmission electron microscope at an accelerating voltage of $100 \mathrm{kV}$ (Hitachi, Tokyo, Japan). In the dip preparations of the sap of cereal plants only spherical particles about $30 \mathrm{~nm}$ in diameter were seen (data not shown). Observations of the sap of C. quinoa leaves with local lesions revealed the presence of both spherical and tobamo-like particles about $300 \mathrm{~nm}$ long (Fig. 2) while in tobacco leaves no spherical and only rod-shaped virions were found (data not shown).

Symptomatic plants were tested by DAS-ELISA (Clark and Adams 1977) using commercial kit detecting Brome mosaic virus (BMV) provided by Loewe Biochemica GmbH (Germany). Positive DAS-ELISA results indicated the virus presence in all symptomatic cereal plants inoculated with 9 water samples as well as in $C$. quinoa leaves. Obtained results revealed important variation in the virus concentration in particular plants. The OD values for infected plants ranged from 0.1 to 2.2. The highest $\mathrm{OD}$ value was obtained for barley. BMV concentration measured from leaves with local lesions in $C$. quinoa increased to the similar level 3-5 dpi but decreased after 2 weeks. Barley plants with distinct mosaic symptoms and with OD value exceeding 0.3 served as materials for further investigations. Other plants were rejected. Thus, only 5 samples named -Ch1, -DBS, -N, -R and -S were propagated in barley, as the maintaining host, in described above greenhouse conditions.

Brome mosaic virus (BMV), the type member of the Bromovirus genus in the family Bromoviridae (Bujarski et al. 2012), is a worldwide occurring pathogen which has a wide host range including both grasses as well as dicotyledonous plants classified into a few genera of approximately six families (Lane 1974). The virus was identified for the first time in Poland by Jeżewska (1999). BMV was considered as a pathogen of minor economical importance (Lane 1981; Brito Alves and Henriques 1993). However, its harmfulness for different cereal species in early stage of development was demonstrated by Pocsai (1987), Pocsai et al. (1991). The BMV genome was one of the first RNA viruses for which the entire 
Fig. 1 Symptoms on plants inoculated with concentrated $(\mathrm{R})$ water sample: (a) systemic leaf mosaic in barley cv. Conchita, (b) local lesion in C. quinoa leaf, (c) systemic necrosis in sweet maize cv. Waza (right plant), on the left healthy plant
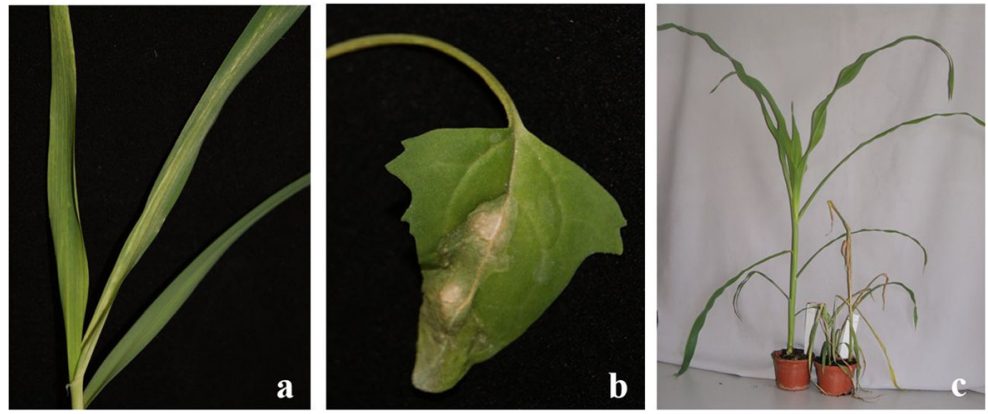

nucleotide sequence was determined (Ahlquist et al. 1981, 1984). The genome is divided into three capped RNAs, designated RNA1 (3.2 kb), RNA2 (2.9 kb) and RNA3 (2.1 kb) which are packaged into three separate viral particles (Bujarski et al. 2012). RNA 1 encodes the 1a protein, RNA2 encodes the 2 a protein which are involved in replication of the viral genome (Ding et al. 1999). The 3 a protein encoded by RNA3 is required for the cell-to-cell movement whereas the subgenomic RNA4 expressed from the 3'-end of RNA3, encodes the coat protein (CP) (Dasgupta and Kaesberg 1982). BMV served primarily as a model of viral RNA replication, recombination and gene expression in plus-stranded
RNA viruses (Kao and Sivakumaran 2000; Wooley and Kao 2004; Scholthof et al. 2011). The broad range of its hosts and easy mechanical transmissibility help the pathogen in its persistence in the environment.

Futher studies of detected viruses were carried out by molecular methods aiming at the final identification as well the evaluation the possible variability of a spherical virus tentatively identified as BMV.

A multiplex reverse transcription - polymerase chain reaction (RT-PCR) technique consisting of one-tube reaction with two differentiating primer pairs was used in order to simultaneous detection of BMV and ToMV and to verify their co-infection, as it was suggested from
Fig. 2 Electron micrograph of BMV particles (arrows) with ToMV rods in leaf dip prepared from infected C. quinoa

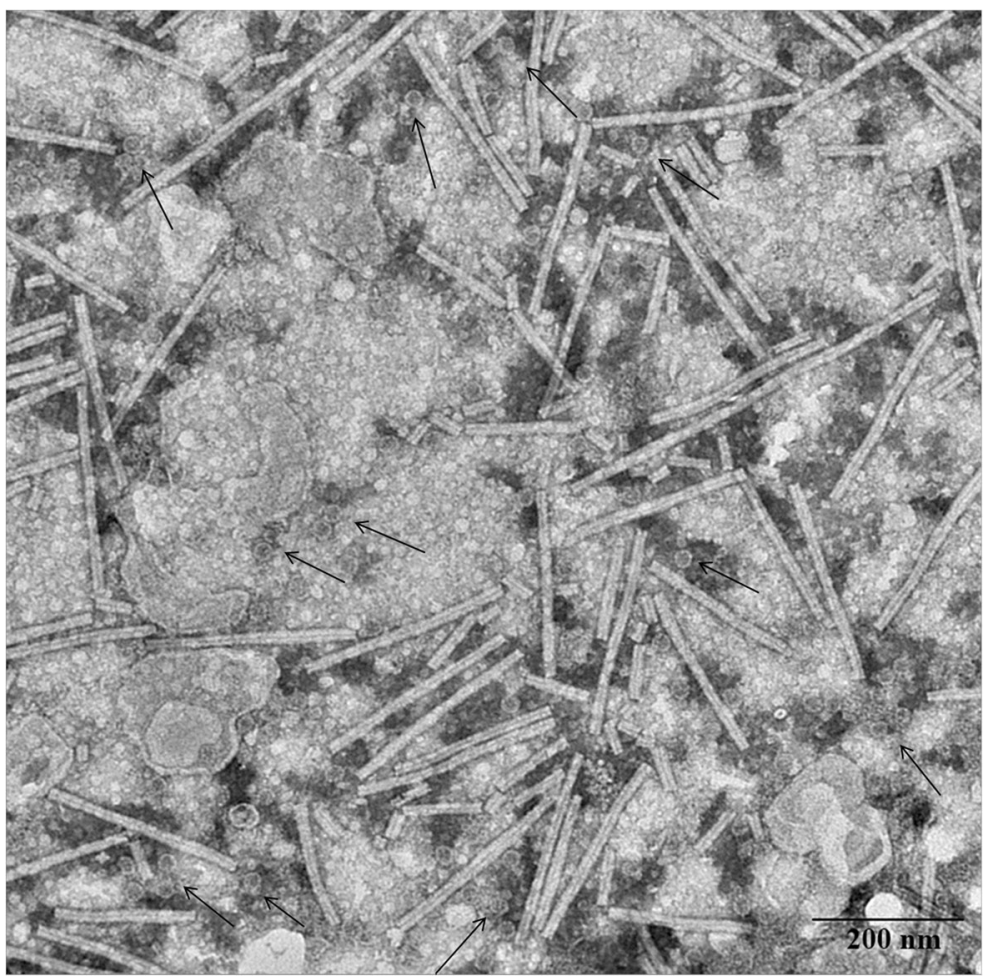


electron microscopic examination of inoculated C. quinoa plants. ToMV was dominating tobamovirus occurring in water samples analyzed previously (Jeżewska et al. 2018). Selected primer pairs: (5'CGAGAGGGGCAACAAACCAT-3'/5'-ACCTGTCT CCATCTCTTTGG-3') (Kumar et al. 2011) and (5'CTATAGCAAAGCGCTTTCGT-3'/5'- CAAACGTA GGGCACACTAGGG-3') (Trzmiel et al. 2015b) amplified 318 bp and 798 bp RT-PCR products within replicase gene of ToMV and BMV, respectively. RT-PCR with three different primer pairs (BMV1-F/BMV1-R, BMV2-F/BMV2-R and BMVcp-F/BMVcp-R) (Trzmiel et al. 2015b), corresponding to each genomic RNAs, were conducted to study BMV variability. The reactions were performed with total RNA samples isolated from symptomatic plants inoculated with selected water samples (Ch1, DBS, N, R and S) using the Total RNA Purification Kit Novazym (Novazym, Poznań, Poland) according to the manufacturer's protocol. First-strand cDNA was obtained with the SuperScript ${ }^{\circledR}$ Reverse Transcriptase (Thermo Fisher Scientific, Waltham, MA, USA) and random hexamer primers following the manufacturer's instructions. PCR samples consisted of $1 \mu \mathrm{l}$ of RT mixture with $0.5 \mu \mathrm{l}$ of each forward and reverse primers $(10 \mu \mathrm{M}), 1 \mu \mathrm{l}$ of $10 \times$ Reaction Buffer with $\mathrm{Mg}^{2+}, 0.4 \mu \mathrm{l}$ of dNTP Mix (10 mM), $0.1 \mu$ of AllegroTaq polymerase DNA (Novazym, Poznań, Poland) and sterile Milli-Q water for a final volume of $10 \mu \mathrm{l}$. The reactions were conducted in thermal conditions described by the primer's authors. DNA amplicons were separated electrophoretically in an 1,5\% agarose gel and stained with Midori Green DNA Stain (NIPPON Genetics Europe GmbH, Düren,
Germany) for UV light visualization. The specificity of obtained RT-PCR products was confirmed by sequencing. RT-PCR products of expected sizes were excised and purified from agarose gel using the Wizard $® S V$ Gel and PCR Clean-Up System (Promega Corp., Madison, WI, USA) then ligated into the pGEM-T Easy Vector (Promega) and transformed into Escherichia coli TOP10 competent cells (Thermo Fisher Scientific), according to the manufacturer's instructions. In the next step, plasmid DNAs were purified using the PureYield ${ }^{\text {TM }}$ Plasmid Miniprep System (Promega), verified by EcoRI (Thermo Fisher Scientific) restrictive digestion and subjected to sequencing in Genomed S.A. (Warsaw, Poland). The nucleotide sequences were analyzed using BLASTN program and compiled using the BioEdit software (Hall 1999).

Multiplex RT-PCR generated products specific for BMV (798 bp) in all analyzed plant samples (data not shown) while specific for ToMV (318 bp) were obtained only for 3 RNA samples derived from $C$. quinoa plants inoculated with R, N and S water samples (Fig. 3). The primer pair detecting ToMV did not generate specific product in tested RNA samples from barley plants. The sequencing results revealed the identity of nucleotide sequence of BMV from barley and from C. quinoa plants inoculated with water samples and their high similarity (99\%) with other known BMV isolates. The obtained nucleotide sequences of ToMV-R, ToMV-N and ToMV-S were identical and characterized previously (Jeżewska et al. 2018).

The set of three specific for BMV RT-PCR products appeared for all analyzed samples isolated from both barley as well as from C. quinoa plants (data not shown).
Fig. 3 Detection of BMV (798 bp band) and ToMV (318 bp band) in C. quinoa samples inoculated with $\mathrm{N}, \mathrm{R}$ and $\mathrm{S}$ concentrated water samples by multiplex RT-PCR. Amplified products were analyzed in $1.5 \%$ agarose gel. M, HyperLadder 100 bp DNA ladder (Bioline); lanes N, R, S, samples co-infected with BMV/ToMV; NTC-, no template control

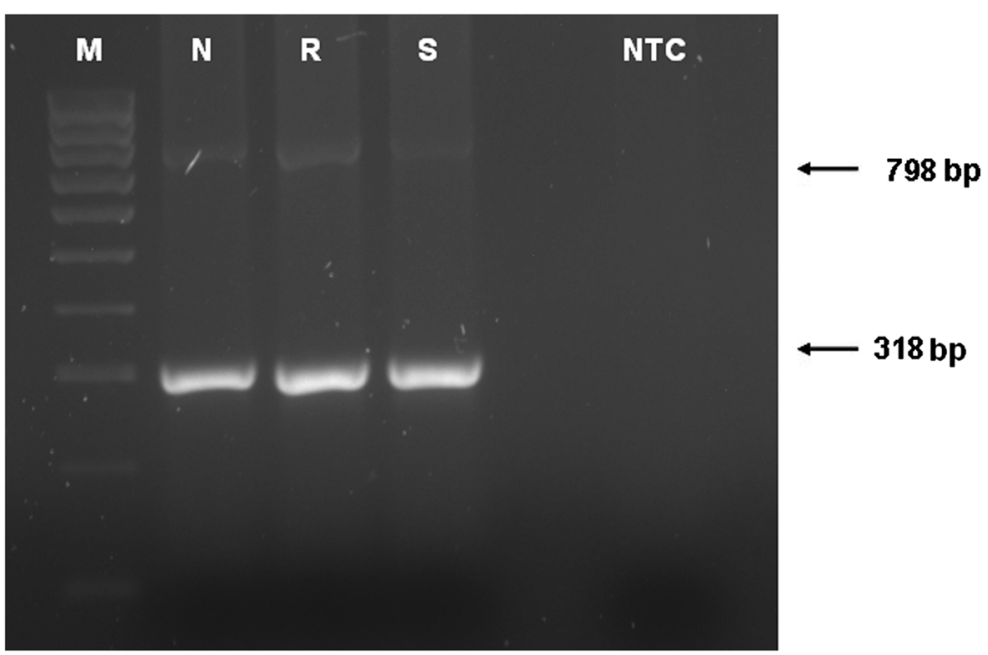


The studies led to determine of genome sequences of RNA1 (830 nt), RNA2 (798 nt) and RNA3 (626 nt) for each of studied BMV samples. The sequenced fragments of RNA1, RNA2 and RNA3 represented 25.7, 27.8 and $29.6 \%$ of the whole BMV genome RNAs, respectively. Results of comparative analysis demonstrated partial nucleotide sequence variability. Obtained genome fragments of BMV-Ch1, BMV-N and BMV-R samples were identical. Therefore BMV-Ch1 was chosen as representative and together with BMV-DBS and BMV-S was selected for next analyses. Partial coding sequences of the 1a, 2a and complete nucleotide sequences of $\mathrm{CP}$ genes were deposited in the NCBI GenBank Database with following accession numbers for: BMV-Ch1 (MG652905, MG652908, MG652911); BMV-DBS (MG652907, MG652910, MG652913) and BMV-S (MG652906, MG652909, MG652912). The nucleotide and amino acid sequences of analyzed BMV isolates were compared with corresponding sequences of other known BMV isolates (Table 1). Results confirmed the highest amino acid homology in the fragment of polymerase $2 \mathrm{a}(99.2 \%-100 \%)$ and the most divergence in CP $(96.2 \%-100 \%)$, as it was previously shown by Gadiou and Kundu (2010).

Phylogenetic analysis of the nucleotide sequences of CP gene was conducted for studied: -Ch1, -DBS, -S and eight previously characterized: $-\mathrm{Sz},-\mathrm{Sr},-\mathrm{Cz}$, -Fescue, $\mathrm{KU} 1,-\mathrm{M} 2$, -Russian and -Estonia BMV isolates as well as with four other species of Bromovirus genus: Cowpea chlorotic mottle virus (CCMV), Cassia yellow blotch virus (CYBV), Spring beauty latent virus (SBLV) and Broad bean mottle virus (BBMV), for which the full length of genome sequences were available in the GenBank database. Olive latent virus (OLV) belonging to Bromoviridae family, Oleavirus genus was used as outgroup. Multiple alignments were performed using the ClustalW software (Thompson et al. 1994). The phylogenetic relationships of the sequences were analyzed by Maximum Likelihood algorithm (ML), choosing best DNA/Protein model $\mathrm{K} 2+\mathrm{G}+\mathrm{I}$ implemented in MEGA6.1 (Tamura et al. 2013). Bootstrap values were calculated using 1000 random replications. Phylogenetic trees were visualized using TreeExplorer implemented in MEGA 6.1 program. The tree topology (Fig. 4) with a well-supported clade of BMV confirmed the species identity of new isolates originated from water samples surrounding fields as well as it showed theirs close relationship to previously characterized Polish isolates - $\mathrm{Sr}$ and $-\mathrm{Sz}$.

The BMV isolates detected in water sources in Poland were characterized by a certain variability of nucleotide sequences within genomic RNA1, RNA2 and CP on RNA3.

BMV was initially regarded as rather homogenous virus species and clearly distinct natural isolates have not been found (Wooley and Kao 2004) although slight

Table 1 Percentage of nucleotide / amino acid sequences identity of different genome regions between BMV-Ch1, BMV-DBS, BMV-S and other known BMV isolates

\begin{tabular}{|c|c|c|c|c|c|c|c|c|c|}
\hline \multirow[t]{2}{*}{ BMV isolate* } & \multicolumn{3}{|c|}{ Replication protein 1a } & \multicolumn{3}{|c|}{ Polymerase $2 \mathrm{a}$} & \multicolumn{3}{|c|}{ Coat protein $\mathrm{CP}$} \\
\hline & BMV-Ch1 & BMV-DBS & BMV-S & BMV-Ch1 & BMV-DBS & BMV-S & BMV-Ch1 & BMV-DBS & BMV-S \\
\hline BMV-Ch1 & & $98.7 / 100$ & $98.6 / 99.6$ & & $97.8 / 100$ & $97.7 / 100$ & & $97.7 / 100$ & $98.5 / 100$ \\
\hline BMV-DBS & $98.7 / 100$ & & $99.8 / 99.6$ & $97.8 / 100$ & & $98.1 / 100$ & $97.7 / 100$ & & $99.1 / 100$ \\
\hline BMV-S & 98.6/99.6 & $99.8 / 99.6$ & & $97.7 / 100$ & $98.1 / 100$ & & $98.5 / 100$ & $99.1 / 100$ & \\
\hline BMV-Sr & $99.2 / 100$ & $98.7 / 100$ & 98.6/99.6 & $97.8 / 100$ & $98.9 / 100$ & $97.8 / 100$ & $99.4 / 98.9$ & $98.2 / 100$ & $99.1 / 100$ \\
\hline BMV-Sz & $98.9 / 100$ & $98.9 / 100$ & $98.7 / 99.6$ & $97.4 / 100$ & $97.8 / 100$ & $99.7 / 100$ & 96.6/98.9 & $96.8 / 100$ & $97.3 / 100$ \\
\hline $\mathrm{BMV}-\mathrm{Cz}$ & $97.8 / 99.6$ & 98.0/99.6 & $97.9 / 99.2$ & $97.7 / 100$ & $98.3 / 100$ & $97.9 / 100$ & $95.9 / 96.2$ & $96.1 / 97.3$ & $96.6 / 97.3$ \\
\hline BMV-Fescue & 99.0/99.6 & $99.0 / 99.6$ & $98.9 / 99.2$ & $97.7 / 99.6$ & 98.6/99.6 & $97.4 / 99.6$ & $97.8 / 98.4$ & $97.8 / 98.9$ & $98.4 / 98.9$ \\
\hline BMV-KU1 & $98.9 / 99.2$ & $98.9 / 99.2$ & $98.7 / 98.9$ & $97.7 / 99.6$ & $98.6 / 99.6$ & $97.9 / 99.6$ & $96.8 / 96.8$ & $97.0 / 97.8$ & $97.5 / 97.8$ \\
\hline BMV-M2 & $99.0 / 99.6$ & $98.7 / 99.6$ & 98.6/99.2 & $97.7 / 99.2$ & $98.6 / 99.2$ & $97.9 / 99.2$ & $97.5 / 98.4$ & $98.0 / 99.4$ & $98.2 / 99.4$ \\
\hline BMV-Rus & 99.0/99.6 & 99.0/99.6 & 98.9/99.2 & $98.1 / 100$ & $98.7 / 100$ & $98.1 / 100$ & $98.0 / 98.4$ & $98.4 / 99.4$ & $98,0 / 99.4$ \\
\hline BMV-Estonia & $98.6 / 100$ & $97.9 / 100$ & $97.8 / 99.6$ & $97.4 / 99.6$ & $97.3 / 99.6$ & $97.2 / 99.6$ & 98.0/98.9 & $97.8 / 100$ & $98.4 / 100$ \\
\hline
\end{tabular}

*GenBank accession numbers of BMV RNA1, RNA2, RNA3 (CP) are given in the following order: -Sr (KP137564-65, KP096132); -Sz (KP161269, KP161267, KP096133); -Cz (GU584129-31); -Fescue (DQ530423-25); -KU1 (X58456-58); -M2 (AB183261-63); -Rus (X02380, X01678, J02042); -Estonia (KU726253-55) 
Fig. 4 Maximum likelihood trees resulting from nucleotide sequence of the CP gene of BMV, SBLV, CCMV, CYBV, BBMV and OLV isolates. The numbers of each major node indicate bootstrapping values (shown only when $>50 \%$ ) out of 1000 replicates. The scale bar shows the number of character substitutions per base to indicate total nucleotide diversity amongst taxa. Examined isolates are marked (red dots)

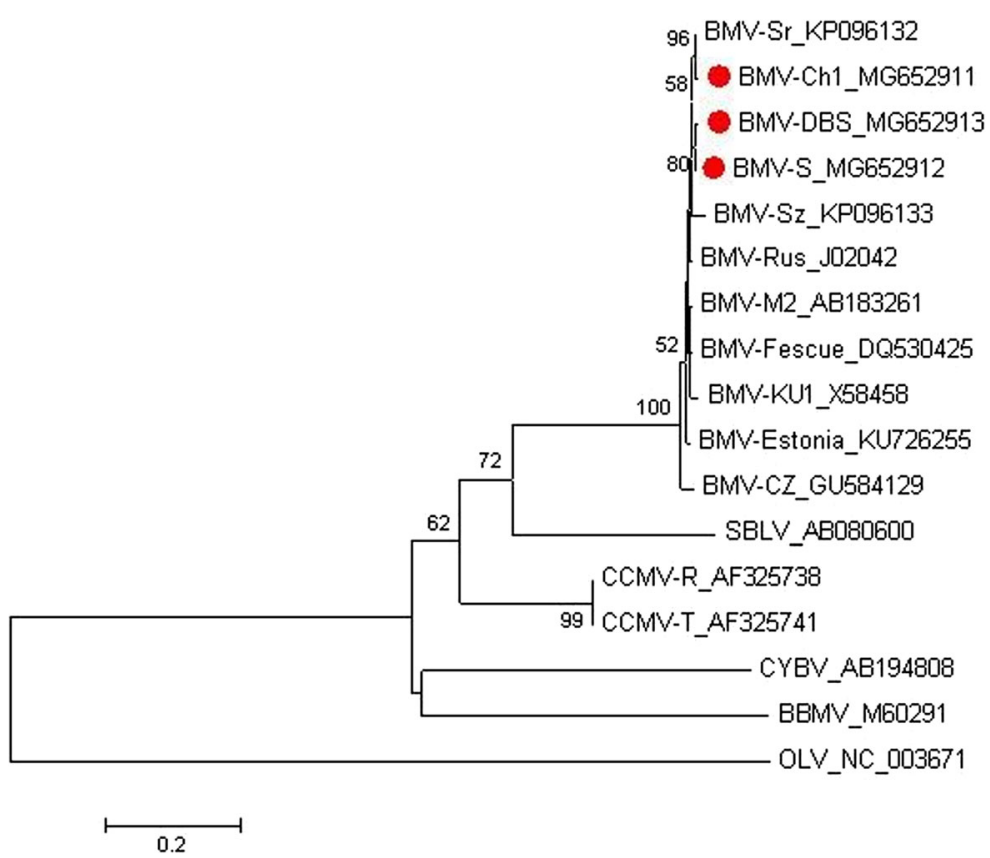

differences in stability host range and other properties have been noted. The majority of studies on BMV infection used the Russian strain (Dasgupta and Kaesberg 1982). First evidence of the BMV variability was provided by Valverde (1983) who described BMV isolates naturally infecting Commelina diffusa and C. communis. Further studies provided reports of following new strains, BMV-KU1 (Mise et al. 1992), BMV-Fescue (Ding et al. 2006), BMV-Czech (Gadiou and Kundu 2010) and recently reported an Estonian isolate (Sömera et al. 2016) as well as an isolate systemically infecting Vigna unguiculata (Trzmiel et al. 2015a and Trzmiel et al. 2016). The variability of BMV isolates is closely associated with the interaction with the virus host (De Jong and Ahlquist 1991). The hostspecific alterations in viral RNA accumulation and infection spread was studied by De Jong and Ahlquist (1995) by comparison of an isolate with expanded host range with a typical one. The authors concluded that several distinct virus functions contribute to the adaptation investigated. De Jong et al. (1995) reported that coding changes in the 3 a cell-to-cell movement gene can extend the host range of BMV systemic infection. The role of the host in BMV RNA replication was reviewed by Noueiry and Ahlquist (2003). Ni et al. (2014) discovered that plant host can affect the encapsidation of BMV RNA and the BMV virions are surprisingly heterogenous. By sequencing of the viral RNAs the authors revealed recombination events in the $3^{\prime}$ untranslated region of RNA1 of BMV purified from barley and wheat but not from tobacco. The authors postulate that previously unexpected heterogeneity in BMV should influence the timing of infection and also the host innate immune responses.

The heterogeneity of the BMV isolates for the first time detected in aqueous environment in Poland remains in agreement with the above presented data concerning molecular differentiation of the virus. The genomic diversification is reflected in modification of the biological properties so the thorough investigation in this aspect should be performed.

Demonstration of relatively high incidence of BMV in water sources surrounding fields confirmed high capacity of the virus to survive out of its host or vector. Nucleotide sequences of RNA fragments of three different BMV isolates, originating from water sources localized in relatively near neighborhood, indicated a certain diversification within the investigated virus group. The obtained data notify the risk of BMV water-infection for a range of cereals.

The virus is the second species belonging to the family Bromoviridae detected in water to date, Cucumber mosaic virus (Cucumovirus) being the first one (Piazolla et al. 1986).

This is the first report on the detection of an infective cereal virus in aqueous environment. 
Authors' contributions MJ designed the research, gathered, analysed the data and wrote the manuscript. KT designed molecular analyses, performed laboratory experiments, and revised the manuscript. A ZN performed electron microscopic observations and revised manuscript. All authors read and approved the final manuscript.

\section{Compliance with ethical standards}

Conflict of interest The authors declare that they have no conflict of interest.

Ethical approval This article does not contain any studies with human participants or animals performed by any of the authors.

Open Access This article is distributed under the terms of the Creative Commons Attribution 4.0 International License (http:// creativecommons.org/licenses/by/4.0/), which permits unrestricted use, distribution, and reproduction in any medium, provided you give appropriate credit to the original author(s) and the source, provide a link to the Creative Commons license, and indicate if changes were made.

\section{References}

Ahlquist, P., Luckow, V., \& Kaesberg, P. (1981). Complete nucleotide sequence of brome mosaic virus RNA3. Journal of Molecular Biology, 153, 23-38.

Ahlquist, P., Dasgupta, R., \& Kaesberg, P. (1984). Nucleotide sequence of brome mosaic virus genome and its implication for virus replication. Journal of Molecular Biology, 172, 369-383.

Brito Alves, M. C., \& Henriques, M. I. C. (1993). Barley stripe mosaic hordeivirus and brome mosaic bromovirus in wheat in Portugal. Phytopathologia Mediterranea, 32, 97-99.

Bujarski, J., Figlerowicz, M., Gallitelli, D., Roossinck, M. J., \& Scott, S. W. (2012). Family Bromoviridae. In A. M. Q. King, E. Lefkowitz, M. J. Adams, \& E. B. Carstens (Eds.), Virus taxonomy: Ninth report of the International Committee on Taxonomy of Viruses (pp. 965-976). London: ELSEVIER.

Clark, M. F., \& Adams, A. N. (1977). Characteristics of the microplate method of enzyme-linked immunosorbent assay for the detection of plant viruses. Journal of General Virology, 34, 475-483.

Dasgupta, R., \& Kaesberg, P. (1982). Complete nucleotide sequence of the coat protein messenger RNAs of brome mosaic virus and cowpea chlorotic mottle virus. Nucleic Acid Research, 10(2), 703-713.

De Jong, W., \& Ahlquist, A. N. (1991). Bromovirus host specificity and systemic infection. Seminars in Virology, 2, 97-105.

De Jong, W., \& Ahlquist, P. (1995). Host-specific alterations in viral RNA accumulation and infection spread in a brome mosaic virus isolate with expanded host range. Journal of Virology, 69(3), 1485-1492.

De Jong, W., Chu, A., \& Ahlquist, P. (1995). Coding changes in the 3a cell-to-cell movement gene can extend the host range of brome mosaic virus systemic infection. Virology, 214, 464 474.
Ding, X. S., Flasiński, S., \& Nelson, R. S. (1999). Infection of barley by brome mosaic virus is restricted predominantly to cells in and associated with veins through a temperaturedependent mechanism. Molecular Plant Microbe Interactions, 12(7), 615-623.

Ding, X. S., Schneider, W. L., Chaluvadi, S. R., Rouf Mian, M. A., \& Nelson, R. S. (2006). Characterization of a Brome mosaic virus strain and its use as a vector for gene silencing in monocotyledonous hosts. Molecular Plant Microbe Interactions, 19(11), 1229-1239.

Gadiou, S., \& Kundu, J. K. (2010). Complete genome sequence of a Brome mosaic virus isolate from the Czech Republic. Czech Journal of Genetics and Plant Breeding, 46, 178-182.

Hall, T. A. (1999). BioEdit: A user-friendly biological sequence alignment editor and analysis program for windows 95/98/ NT. Nucleic Acids Symposium Series, 41, 95-98.

Jeżewska, M. (1999). Some properties of an isolate of Brome mosaic virus. Phytopathologia Polonica, 17, 23-30.

Jeżewska, M., Trzmiel, K., \& Zarzyńska-Nowak, A. (2018). Detection of infectious tobamoviruses in irrigation and drainage canals in greater Poland. Journal of Plant Protection Research. https://doi.org/10.24425/119126.

Kao, C. C., \& Sivakumaran, K. (2000). Brome mosaic virus, good for an RNA virologist's basic needs. Molecular Plant Pathology, 1(2), 91-97.

Kumar, S., Udaya Shankar, A. C., Nayaka, S. C., Lund, O. S., \& Prakash, H. S. (2011). Detection of Tobacco mosaic virus and Tomato mosaic virus in pepper and tomato by multiplex RTPCR. Letters in Applied Microbiology, 53, 359-363.

Lane, L. C. (1974). The Bromoviruses. In M. A. Lauffer, F. B. Bang, K. Maramorosch, \& K. M. Smith (Eds.), Advances in Virus Research (Vol. 19, pp. 151-220). New York: Academic Press.

Lane, L. C. (1981). Bromoviruses. In E. Kurstak (Ed.), Handbook of plant virus infections and comparative diagnosis (pp. 333376). Amsterdam: Elsevier Biomedical Press.

Mehle, N., \& Ravnikar, M. (2012). Plant viruses in aqueous environment - Survival, water mediated transmission and detection. Water Research, 46, 4902-4917.

Mise, K., Tsunge, S., Nagao, K., Okuno, T., \& Furusawa, I. (1992). Nucleotide sequence responsible for the synthesis of a truncated coat protein of brome mosaic virus strain ATCC66. Journal of General Virology, 73, 2543-2551.

Ni, P., Vaughan, R. C., Tragesser, B., Hoover, H., \& Kao, C. C. (2014). The plant host can affect the encapsidation of brome mosaic virus (BMV) RNA: BMV virions are surprisingly heterogenous. Journal of Molecular Biology, 426, 1061-1076.

Noueiry, A. O., \& Ahlquist, P. (2003). Brome mosaic virus RNA replication: Revealing the role of the host in RNA virus replication. Annual Review of Phytopathology, 41, 77-98.

Piazolla, P., Castellano, M. A., \& de Stradis, A. (1986). Presence of plant viruses in some rivers of southern Italy. Journal of Phytopathology, 116, 244-246.

Pocsai, E. (1987). Effect of brome mosaic infection of the plant height and weight of cereals at their early stages of growth. Cereal Research Communications, 15(203), 167-174.

Pocsai, E., Kobza, S., Muranyi, I., \& Szunics, L. (1991). Brome mosaic virus infection in different cereal breeding materials. Acta Phytopathologica et Entomologica Hungarica, 26(12), 207-212.

Scholthof, K. B. G., Adkins, S., Czosnek, H., Palukaitis, P., Jacquot, E., Hohn, T., Hohn, B., Saunders, K., Candresse, 
T., Ahlquist, P., Hemenway, C., \& Foster, G. D. (2011). Top 10 plant viruses in molecular plant pathology. Molecular Plant Pathology, 12(9), 938-954.

Sömera, M., Gantsovski, M., \& Truve, E. (2016). First report of Brome mosaic virus in wheat in Estonia. Plant Disease, $100(10), 2175$.

Tamura, K., Stecher, G., Peterson, D., Filipski, A., \& Kumar, S. (2013). MEGA6: Molecular Evolutionary Genetics Analysis Version 6.0. Molecular Biology and Evolution, 30, 2725-2729.

Thompson, J. D., Higgins, D. G., \& Gibson, T. J. (1994). CLUSTAL W: Improving the sensitivity of progressive multiple sequence alignment through sequence weighting, position-specific gap penalties and weight matrix choise. Nucleic Acids Research, 22(22), 4673-4680.

Trzmiel, K., Szydło, W., Zarzyńska-Nowak, A., \& Jeżewska, M. (2015a). First report of Brome mosaic virus (BMV) and Wheat streak mosaic virus (WSMV) co-infection in triticale plants in Poland. Plant Disease, 99(9), 1290.
Trzmiel, K., Wielkopolan, B., \& Lewandowska, M. (2015b). Zastosowanie techniki RT-PCR do wykrywania wirusa mozaiki stokłosy (Brome mosaic virus, BMV) w skrzypionce zbożowej (Oulema melanopus L.). Progress in. Plant Protection, 55(4), 494-497.

Trzmiel, K., Zarzyńska-Nowak, A., Lewandowska, M., \& Szydło, W. (2016). Identification of new Brome mosaic virus (BMV) isolates systemically infecting Vigna unguiculata L. European Journal of Plant Pathology, 145, 233-238.

Valverde, R. A. (1983). Brome mosaic virus isolates naturally infecting Commelina diffusa and C. communis. Plant Disease, 67, 1194-1196.

Wooley, R.S., Kao, C.C. (2004). Brome mosaic virus. CMI/AAB Descriptions of Plant Viruses, No 405, 4 pp. https://stat.gov. pl/obszary-tematyczne/roczniki-statystyczne/rocznikistatystyczne/maly-rocznik-statystyczny-polski-2017,1,18. html, Accessed 15 July 2017. 